\title{
APPLICATION OF WATER EQUIVALENTS METHOD TO CALCULATION OF CERAMIC HEAT EXCHANGERS
}

\section{Notation:}

$\mathrm{c}_{a}$ - heat capacity of air, $\mathrm{kJ} /\left(\mathrm{m}^{3} \cdot \mathrm{K}\right)$,

$\mathrm{c}_{g}$ - heat capacity of furnace gas, $\mathrm{kJ} /\left(\mathrm{m}^{3} \cdot \mathrm{K}\right)$,

$D, d$ - diameter, $\mathrm{m}$,

$\varepsilon-$ heat effectiveness,

$F$ - heating surface area, $\mathrm{m}^{2}$,

$k$ - over-all heat-transfer coefficient, $\mathrm{W} /\left(\mathrm{m}^{2} \cdot \mathrm{K}\right)$,

$\mathrm{N}$ - Number of Heat Transfer Units,

$T, t$ - temperature, $\mathrm{K},{ }^{\circ} \mathrm{C}$,

$V-$ volumetric rate of fluid flow, $\mathrm{m}^{3} / \mathrm{h}, \mathrm{m}^{3} / \mathrm{s}$,

$W_{a}$ - water equivalent of air, $\mathrm{W} / \mathrm{K}$,

$W_{g}$ - water equivalent of furnace gas, $\mathrm{W} / \mathrm{K}$.

\section{INTRODUCTION}

Ceramic recuperators are used for the recovery of heat from waste gases with industrial heat furnaces and glass tanks [1, 2, 3, 5]. In ZM Ropczyce [10] production of new generation magnesia shapes to ceramic recuperators was developed and included to glass furnaces. On account of material costs the ceramic recuperator are calculated by mathematical

* Ph.D.: Faculty of Metals Engineering and Industrial Computer Sciences, AGH - University of Science and Technology, Kraków, Poland; e-mail: ztc@agh.edu.pl 
method to achieve required construction and service characteristic for minimal number of shapes. For calculation of ceramic recuperator made of new generation shapes the balance method were elaborated [5]. In calculation of heat exchangers the water equivalents method is very important $[7,8,9]$. This method is more universal than balance method. The aim of this paper is presentation of mathematic model and calculation algorithm by water equivalents method the ceramic recuperator made of magnesia shapes.

\section{SIMILARITY FUNCTION USED TO CALCULATE THE HEATING SURFACE OF CROSS-FLOW CERAMIC HEAT EXCHANGERS}

Ceramic recuperators belong to cross-flow heat exchangers group. The water equivalent method enables to calculate the construction parameters of heat exchangers. In recuperators recovered furnace gas from industrial furnaces water equivalent of furnace gas is:

$$
W_{g}=V_{g} c_{g}
$$

where:

$V_{g}$ - volumetric rate of furnace gas flow,

$c_{g}$ - heat capacity of furnace gas.

Water equivalent of air is:

$$
W_{a}=V_{a} c_{a}
$$

where:

$V_{a}$ - volumetric rate of air,

$c_{a}$ - heat capacity of air.

Water equivalent of furnace gas is bigger than air water equivalent:

$W_{g}>W_{a}$

The similarity function (Fig. 1) used in cross-flow heat exchangers is [4, 9] expressed by equation:

$$
\begin{aligned}
& \varepsilon=f\left(\frac{W_{g}}{W_{a}}, \mathrm{~N}\right) \\
& \varepsilon=\frac{t_{a}^{\prime \prime}-t_{a}^{\prime}}{t_{g}^{\prime}-t_{a}^{\prime}}
\end{aligned}
$$

where:

$t_{a}^{\prime \prime}$ - air preheated temperature outlet,

$t_{a}^{\prime}$ - air temperature inlet to recuperator,

$t_{g}^{\prime}$ - furnace gas temperature inlet to recuperator,

$\mathrm{N}$ - Number of Heat Transfer Units. 
a)

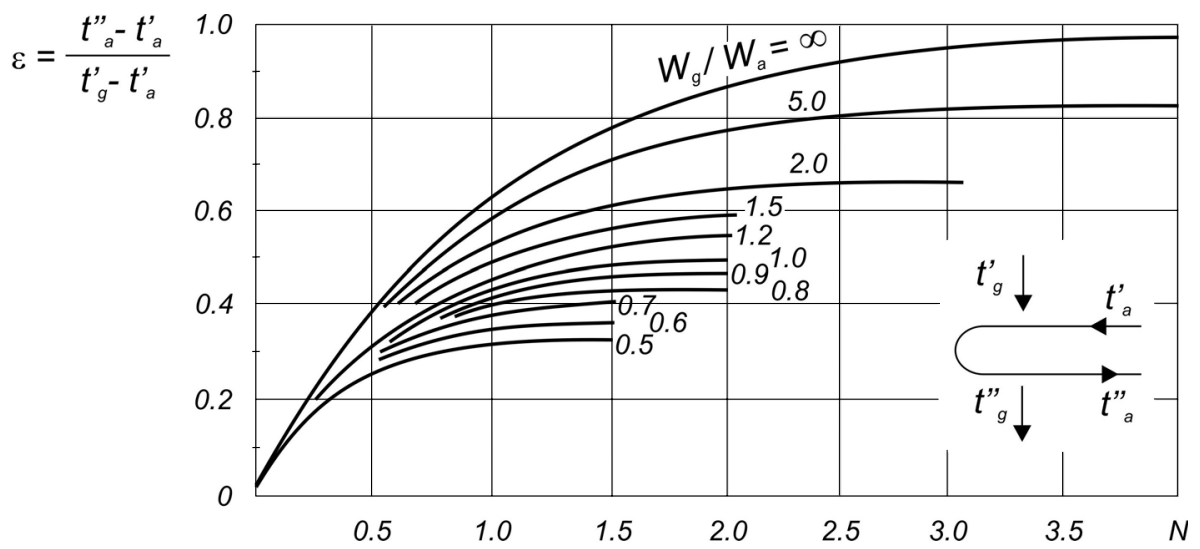

b)

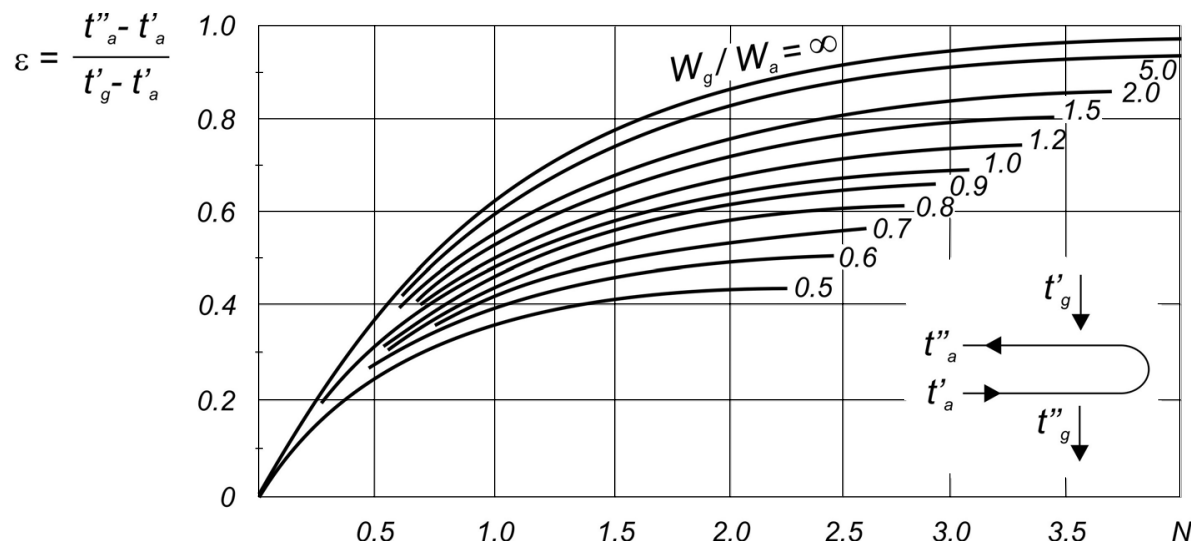

Fig. 1. Similarity function $\varepsilon=f\left(\frac{W_{g}}{W_{a}}, \mathrm{~N}\right)$ used in cross-flow exchangers [9]:

a) parallel flow; b) counter flow

The Number of Heat Transfer Units is the measure of heat surface area and is expressed by equation:

$$
\mathrm{N}=\frac{k F}{W_{a}}
$$

where:

$k$ - over-all heat transfer coefficient,

$F$ - heat transfer surface area,

$W_{a}$ - water equivalent of air. 


\section{THE CALCULATION OF CERAMIC HEAT EXCHANGERS BY WATER EQUIVALENT METHOD}

The proposed algorithm of calculation of ceramic recuperator consists equation.

The volumetric rate of air outlet from recuperator is

$$
V_{a}^{\prime}=\frac{V_{a}}{1-n}
$$

where $n$ - untight of air channel.

The arithmetic mean of volumetric rate of air

$$
\bar{V}_{a}=\frac{V_{a}^{\prime}+V_{a}}{2}
$$

The absolute untight of air equals

$$
\Delta V_{a}=V_{a}^{\prime}-V_{a}
$$

The volumetric rate of furnace gas outlet from recuperator is

$$
V_{g}^{\prime \prime}=V_{g}^{\prime}+\Delta V_{a}
$$

The air water equivalent is

$$
W_{a}=\bar{V}_{a} c_{a}
$$

where $c_{a}$ - heat capacity of air.

The arithmetic mean of volumetric rate of furnace gas is

$$
\bar{V}_{g}=\frac{V_{g}^{\prime}+V_{g}^{\prime \prime}}{2}
$$

The furnace gas water equivalent equals

$$
W_{g}=\bar{V}_{g} c_{g}
$$

where $c_{g}$ - heat capacity of furnace gas.

The microfinned surface area of ceramic recuperator is

$$
F=\frac{\mathrm{N} W_{a}}{k}
$$

where:

$\mathrm{N}$ - Number of Heat Transfer Units,

$W_{a}$ - water equivalent of air,

$k$ - over-all heat transfer coefficient. 


\section{THE CALCULATIONS OF CERAMIC RECUPERATOR TO GLASS TANK}

The ceramic recuperator uses a heat of waste gas from glass tank. Preheating in recuperator air is used directly in combustion of fuel. The recuperator works in cross-flow and has the following parameters:

- volumetric rate of air

$$
\begin{aligned}
V_{a} & =1000 \mathrm{~m}^{3} / \mathrm{h}\left(0.278 \mathrm{~m}^{3} / \mathrm{s}\right), \\
t_{a}^{\prime} & =20^{\circ} \mathrm{C}, \\
t_{a}^{\prime \prime} & =600^{\circ} \mathrm{C}, \\
V_{g}^{\prime} & =1200 \mathrm{~m}^{3} / \mathrm{h}\left(0.33 \mathrm{~m}^{3} / \mathrm{s}\right), \\
t_{g}^{\prime} & =1300^{\circ} \mathrm{C} .
\end{aligned}
$$

- inlet furnace gas to recuperator

The recuperator made of magnesia shapes illustrates Figure 2 with the following dimensions:

- outer diameter of tube

$$
\begin{aligned}
& D=0.187 \mathrm{~m}, \\
& d=0.145 \mathrm{~m}, \\
& s=0.021 \mathrm{~m}, \\
& h=0.312 \mathrm{~m}, \\
& h_{1}=0.232 \mathrm{~m}, \\
& p=0.11 \mathrm{~m} .
\end{aligned}
$$

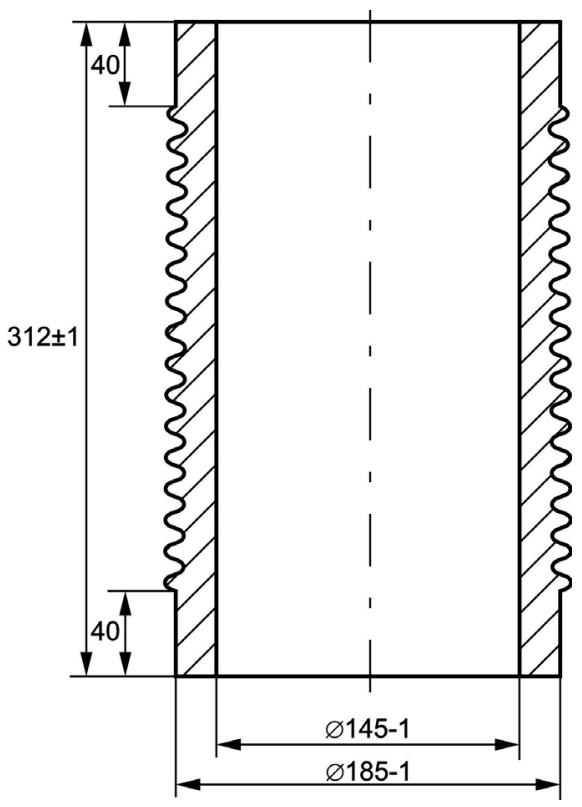

Fig. 2. Magnesia M98G recuperator shape 
The volumetric rate of air inlet to recuperator is:

$$
V_{a}^{\prime}=\frac{V_{a}}{1-n}=\frac{1000}{1-0.15}=1176 \mathrm{~m}^{3} / \mathrm{h}\left(0.327 \mathrm{~m}^{3} / \mathrm{s}\right),
$$

where $n$ - untight of air channel.

The arithmetic mean of volumetric rate of air is:

$$
\bar{V}_{a}=\frac{V_{a}+V_{a}^{\prime}}{2}=\frac{0.278+0.327}{2}=0.303 \mathrm{~m}^{3} / \mathrm{s} .
$$

The absolute untight of air equals:

$$
\Delta V_{a}=V_{a}^{\prime}-V_{a}=1176-1000=176 \mathrm{~m}^{3} / \mathrm{h} .
$$

The volumetric rate of furnace gas outlet from recuperator is:

$$
V_{g}^{\prime \prime}=V_{g}^{\prime}+\Delta V_{a}=1200+176=1376 \mathrm{~m}^{3} / \mathrm{h}=0.382 \mathrm{~m}^{3} / \mathrm{s} .
$$

The air water equivalent is:

$$
W_{a}=\bar{V}_{a} c_{a}=0.303 \cdot 1350=409.1 \mathrm{~W} / \mathrm{K},
$$

where heat capacity of air $c_{a}=1350 \mathrm{~J} /\left(\mathrm{m}^{3} \cdot \mathrm{K}\right)$.

The arithmetic mean of volumetric rate of furnace gas equals:

$$
\bar{V}_{g}=\frac{V_{g}^{\prime}+V_{g}^{\prime \prime}}{2}=\frac{0.333+0.382}{2}=0.358 \mathrm{~m}^{3} / \mathrm{s} .
$$

The furnace gas water equivalent is:

$$
W_{g}=\bar{V}_{g} c_{g}=0.358 \cdot 1640=587.1 \mathrm{~W} / \mathrm{K} \text {, }
$$

where heat capacity of furnace gas $c_{g}=1640 \mathrm{~J} /\left(\mathrm{m}^{3} \cdot \mathrm{K}\right)$.

The simplex of water equivalent is:

$$
\frac{W_{g}}{W_{a}}=\frac{587.1}{409.1}=1.44 .
$$


The heat effectiveness of recuperator is expressed by equation:

$\varepsilon=\frac{t_{a}^{\prime \prime}-t_{a}^{\prime}}{t_{g}^{\prime}-t_{a}^{\prime}}=\frac{600-20}{1300-20}=0.45$

The Number of Heat Transfer Units by Figure $1 \mathrm{~b}$ is $\mathrm{N}=0.8$.

The over-all heat-transfer coefficient is $k=7.5 \mathrm{~W} /\left(\mathrm{m}^{2} \cdot \mathrm{K}\right)$.

The surface area of recuperator is

$$
F=\frac{\mathrm{N} W_{a}}{k}=\frac{0.8 \cdot 409.1}{7.5}=43.6 / \mathrm{m}^{2}
$$

The number of shapes in recuperator equals:

$L=\frac{F}{f_{1}}=\frac{43.6}{0.136}=321$, admitted 336.

The heat surface area [10] of ceramic shape is $f_{1}=0.136 \mathrm{~m}^{2}$.

The recuperator row of shapes in lager is:

$x \cdot y=8 \cdot 7=56$.

The number of rows on height of recuperator equals:

$$
z=\frac{L}{56}=\frac{336}{56}=6
$$

The ceramic heat exchanger chambers over-all dimensions are the following:

- length $-8 \cdot 0.187+8 \cdot 0.11=2.4 \mathrm{~m}$,

- width $-7 \cdot 0.187+7 \cdot 0.11=2.1 \mathrm{~m}$,

- height $-6 \cdot 0.312+0.52=2.4 \mathrm{~m}$.

The heat surface areas calculated by balance method [6] is $45.3 \mathrm{~m}^{2}$.

The heat surface area calculated by water equivalents method is $43.6 \mathrm{~m}^{2}$.

The differences of surface is:

$$
\Delta=\frac{45.3-43.6}{45.3} \cdot 100 \%=3.8 \%
$$

The ceramic recuperator to glass tank using Glasmag M98G materials illustrates Figure 3. 


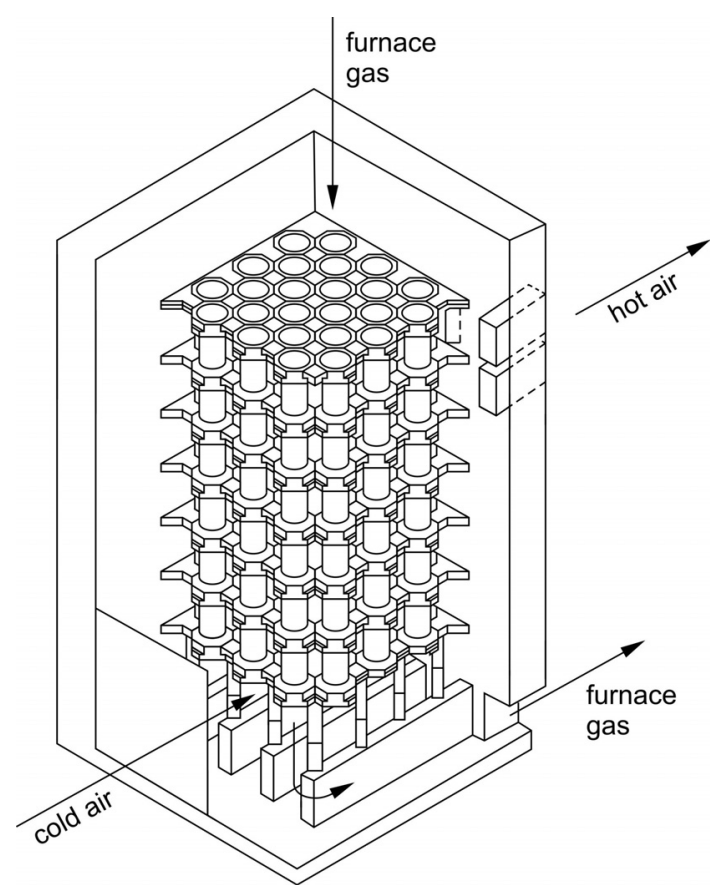

Fig. 3. Ceramic recuperator to tank furnace

\section{INFERENCES}

- Ceramic exchangers using energy of flue gases from glass melting furnaces on account of high-temperature, dust, and thermal shocks work in very difficult conditions.

- The service life of glass melting tanks is determined by effectiveness of heat exchangers. Therefore new models of ceramic recuperators made of magnesia or aluminamullite-zircona shapes are introduce into service.

- By water equivalents method mathematic model and algorithm of calculations the recuperators made of magnesia shapes were elaborated.

- This model makes possible to define recuperator's design: over all dimensions, heat surface area and lattice work of shapes.

- By the model ceramic recuperator to glass melting tank were calculated. The difference of heat surface areas calculated by balance method and water equivalents method is $3.8 \%$.

\section{REFERENCES}

[1] Karczewski K.: Metallic Recuperators to Glass Tanks, Technical University of Kosice, Kosice, 1998

[2] Karczewski K.: Wpływ mikroużebrowania powierzchni równoległoprądowych rekuperatorów metalowych na ich cechy konstrukcyjne i eksploatacyjne, UWND AGH, Kraków, 2000 
[3] Karczewski K.: Foundry and Metallurgy Engineering, 29 (2003) 47-65

[4] Karczewski K.: Obliczenia cieplne rekuperatorów metalowych dla pieców przemysłowych, UWND AGH, Kraków, 2004, SU 1667

[5] Karczewski K.: Metallurgy and Foundry Engineering, 32 (2006) 47-65

[6] Karczewski K.: Metallurgy and Foundry Engineering, 34 (2008) 39-50

[7] Mikheyev M.: Fundamentals of Heat Transfer. Mir Publishers, Moscow, 1968

[8] Senkara T.: Obliczenia pieców grzewczych w hutnictwie żelaza, Wyd. Śląsk, Katowice, 1983

[9] Tajc N.: Raszczety nagrewatielnych pieczej. Mietałłurgija, Moscow, 1969

[10] Catalog: Glass-Making Industry, ZM Ropczyce, 2004

Received

November 2009 